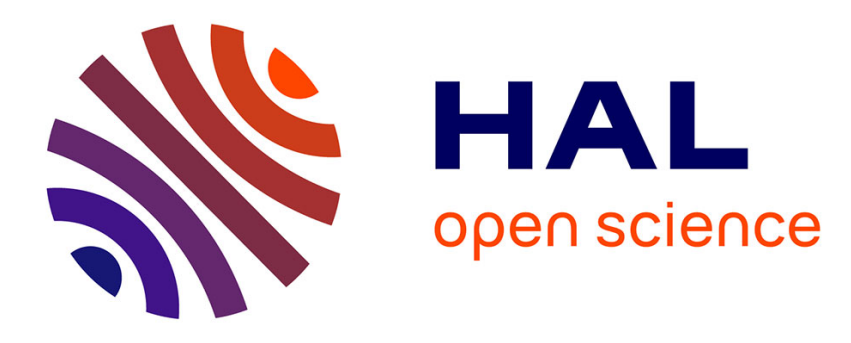

\title{
Tense marking on dependent nominals in Movima
}

Katharina Haude

\section{To cite this version:}

Katharina Haude. Tense marking on dependent nominals in Movima. Musan, Renate et Monika Rathert. Tense across languages, De Gruyter, pp.189-206, 2011. halshs-00672248

\section{HAL Id: halshs-00672248 \\ https://shs.hal.science/halshs-00672248}

Submitted on 20 Feb 2012

HAL is a multi-disciplinary open access archive for the deposit and dissemination of scientific research documents, whether they are published or not. The documents may come from teaching and research institutions in France or abroad, or from public or private research centers.
L'archive ouverte pluridisciplinaire HAL, est destinée au dépôt et à la diffusion de documents scientifiques de niveau recherche, publiés ou non, émanant des établissements d'enseignement et de recherche français ou étrangers, des laboratoires publics ou privés. 


\section{Katharina Haude}

\section{Tense marking on dependent nominals in Movima ${ }^{1}$}

\section{Introduction}

In Movima, an endangered, unclassified language of the Bolivian Amazon area, tense is not marked on verbs, but on dependent nominals. Consider the difference between (1), where the temporal interpretation is context-dependent, and (2), where past tense is indicated by the form of the neuter article. ${ }^{2}$

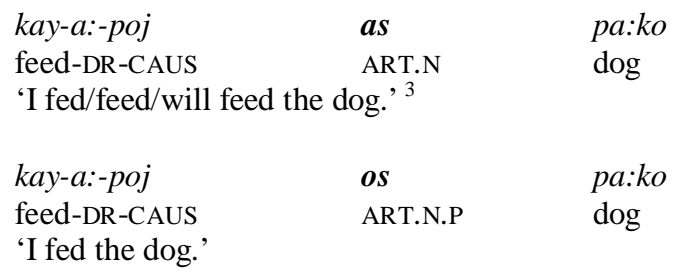

The different temporal interpretations of (1) and (2) result from the fact that, as will be described in detail below, the article as in (1) indicates that the referent of the noun phrase is present at the speech situation, while $o s$ in (2) indicates that the referent does not exist anymore. In other words, the noun phrase marks a temporal distinction, a phenomenon that can be described as "nominal tense marking" (Nordlinger and Sadler 2004).

The paper is structured as follows. In Section 2 I present some basic features of Movima

1 This paper is a slightly extended version of Haude (2010b) and was prepared within the Movima documentation project of the DoBeS programme (Volkswagenstiftung). I am grateful to the Movima speakers who taught me their language, in particular to the ones who contributed the examples presented here: Esaltación Amblo, Julia Malale, Balvina Almaquio, Eligardo Chirimani, Etelvina Gualusna, Griselda Cáumol, Herlan Rojas. I furthermore wish to thank Albert Ortmann and an anonymous reviewer for very helpful comments on a previous version of the manuscript.

2 Abbreviations in the glosses are: $\mathrm{A}=$ absential; $\mathrm{ANT}=$ anterior; $\mathrm{APPL}=$ applicative; $\mathrm{ART}=$ article; $\mathrm{BE}=$ bound nominal element; $\mathrm{BR}=$ bound root; $\mathrm{CAUS}=$ causative; $\mathrm{DEM}=$ demonstrative; $\mathrm{DR}=$ direct; DUR=durative; $\mathrm{DSC}=$ discontinuous; $\mathrm{EV}=\mathrm{evidential;} \mathrm{F}=\mathrm{feminine} ; \mathrm{HAB}=$ habitual; INAL=inalienable; IMM=immediate past; IMP=imperative; INTR=intransitive; IRR=irrealis; ITN=intentional; LV=linking vowel; $\mathrm{M}=$ masculine; $\mathrm{MD}=$ middle; $\mathrm{MLT}=$ multiple; $\mathrm{MOD}=$ modal; $\mathrm{N}=$ neuter; $\mathrm{NMZ}=$ nominalization; NSTD=nonstanding; $\quad \mathrm{OBL}=$ oblique; $\mathrm{P}=$ past; $\mathrm{PL}=$ plural; $\mathrm{PRO}=$ free pronoun; $\mathrm{REL}=$ relativizer; REM=remote past; $\mathrm{R} / \mathrm{R}=$ reflexive/reciprocal; $\mathrm{SG}=$ singular; $\mathrm{STD}=$ standing. The symbol -- represents "external cliticization", which marks the obviative argument and contrasts phonologically with "internal cliticization" (represented as =), which marks the proximate argument (see Haude 2006: 97ff.; Haude 2009b). The symbols for reduplication and $<>$ for infixation stem from the Leipzig Glossing Rules.

3 The first person singular is not overtly marked on transitive verbs and possessed nominals. 
clause structure (2.1.) and show that Movima does not have verbal tense-marking morphology (2.2.), tense, aspect and mood (TAM) categories being encoded by particles (2.3.). I will then give an account of the system of referential elements, in particular, the article (Section 3). It will be shown how the Movima article indicates spatial and temporal properties of concrete referents (3.1.), how a three-way temporal distinction is made on noun phrases referring to times and events (3.2.), and how noun phrases referring to absolute concepts are immune to temporal marking (3.3.). In Section 4, I discuss the notions of propositional and independent nominal tense marking with regard to the Movima article: while it encodes the temporal properties of entities, and hence functions independently of the clausal tense, the form of the article by implicature determines the temporal interpretation of the clause as well (4.1.). Moreover, the article can serve to mark temporal reference in discourse not only implicitly, but also directly (4.2). It is postulated that the article gradually shifts from an independent to a propositional tense marker (4.3.). In Section 5 I briefly address some problems related to the concept of nominal tense marking.

The data on which the analysis is based were collected in Santa Ana del Yacuma, Bolivia, between 2001 and 2004. Most of the data presented here stem from spontaneous discourse (marked with [tx]), the rest is elicited.

\section{The lack of verbal tense morphology}

\subsection{Basic features of Movima clause structure}

The core of a Movima clause is typically predicate initial. Arguments are represented by bound or free pronouns or by noun phrases, which consists of an article and a content word. Example (3) illustrates a transitive clause, which consists of a predicate and two noun phrases (in square brackets) representing the arguments. ${ }^{4}$

$$
\begin{aligned}
& \text { man }<a>y e=[i s \text { pa:ko] [os rulrul] } \\
& \text { encounter }\langle\text { DR }>=\text { ART.PL dog ART.N.P jaguar } \\
& \text { 'The dogs met the/a jaguar.' [tx] }
\end{aligned}
$$

Adjuncts are marked by the oblique case marker $n$-, as illustrated in the intransitive clause in $(4):^{5}$

$$
\text { ilo:ni--y'ti n-os chapmo }
$$

4 The article of the first argument phrase in a transitive clause is cliticized phonologically to the predicate (see Haude 2009b).

5 The cliticization processes mark as -- ("external cliticization") applies to pronouns representing the single argument of intransitive clauses and the obviative argument of transitive clauses. It contrasts with "internal cliticization" ( = ), which marks the proximative argument of transitive clauses (see Haude 2009b). 

walk--1PL
OBL-ART.N.P
forest
'We walked in the forest.'
[tx]

The content word in a noun phrase can be a morphological noun, as in the above examples, but it can also be a verb, in which case the phrase refers to a participant in the event. In turn, a content word that is not preceded by an article, but for example accompanied by a pronoun, is automatically interpreted as a predicate (see Haude 2009a). Compare the noun phrase in (5)a with the predicate in (5)b, both headed by the word pa:toronay' $i$ 'our landlord':
a.
kus
ART.M.A
pa:toron- $a=y^{\prime} t i$
landlord-LV=1PL
'our landlord'
b. usko pa:toron- $a=y^{\prime}$ 'i
PRO.3M.A landlord-LV=1PL
'He (is/was) our landlord.' [tx]

The examples in (6) illustrate the same contrast with a morphological verb, yeynan 'you want' (see Haude 2010a for discussion):
a. $\quad$ is $\quad y e y-n a=n$
ART.PL want-DR=2
'the ones you want(ed)'
[tx]
b. i'ko yey-na=n
PRO.3PL want-DR=2
'You want(ed) those.' [tx]

Thus, noun phrases can contain nouns as well as verbs, but in either case, they establish reference. ${ }^{6}$ While perhaps not fully adequate, I use the term "noun phrase" because functionally, reference is a nominal property (Croft 2003), and the categories encoded by the article can be considered nominal.

\subsection{The lack of verbal tense morphology}

Movima has no verbal tense marking morphology. Depending on the context, the clause in (7) can either have a past, present, or future interpretation.

$$
\begin{aligned}
& \text { yolmot--isne } \\
& \text { stroll--3F.A }
\end{aligned}
$$

6 As can be seen in (6), an NP containing a verb refers to an event participant. In the case of eventor state-denoting NPs, an explicit morphological nominalizer is used (see 3.2). 
'She (absent) went / is going / will go for a walk.'

The only verbal affix that can have a temporal reading is the irrealis infix $\langle(k) a k\rangle{ }^{7}$ In affirmative contexts, it indicates that the speaker believes that the situation will take place some time in the future:

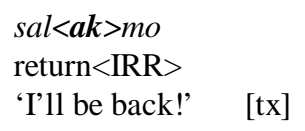

Aspect affixes in Movima cover meanings such as "repeatedly" or "at once". None of them locates the denoted situation temporally. On the whole, the major TAM categories are expressed through particles, most of which are not formally related to the verb. I will give an outline of the relevant particles in the following section.

\subsection{TAM particles}

Movima has a large array of particles and adverbs that express temporal, modal, and aspectual categories. Temporal relations are mainly established by the following ones:

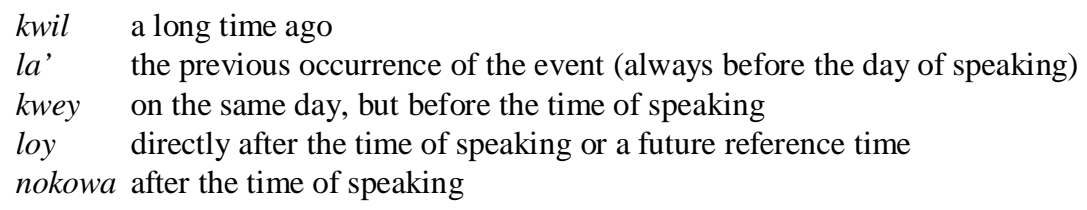

As will also become apparent below (Section 3.2.), the major temporal categories in Movima are "past" (before the day of speaking), "immediate past" (on the same day, but before the time of speaking), and non-past. Accordingly, the above particles can be grouped into two forms pertaining to the past ( $k w i l$ and $l a^{\prime}$ ), one that pertains to the immediate past (kwey), and two that pertain to non-past (loy and nokowa).

The following examples illustrate the way in which these particles convey temporal meanings. Examples (10) and (11) illustrate the particles kwil and la'. They occur frequently inside an NP (i.e., between the article and the following content word), which shows that they are not syntactically part of the verb phrase.

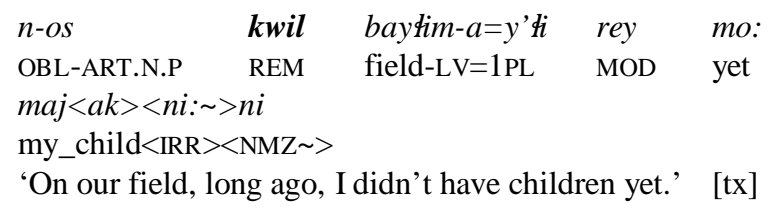

7 This morpheme is inserted after the first iambic foot of the base. It appears with an initial $/ \mathrm{k} / \mathrm{after}$ vowels (see Haude 2006: 78ff.). 


$$
\begin{array}{llll}
\text { jo'yaj--us } & \text { n-os } & \multicolumn{1}{l}{\boldsymbol{a}^{\prime}} & \text { walaylo } \\
\text { arrive--3M.A } & \text { OBL-ART.N.P } & \text { ANT } & \text { afternoon } \\
\text { 'He arrived yesterday afternoon.' (lit.: “on the previous afternoon.") } & \text { [tx] }
\end{array}
$$

The "immediate past" particle kwey usually occurs before the predicate, as in (12), but it can also occur inside an NP, as shown in (13):

$\begin{array}{llll}\begin{array}{l}\text { kwey joy-chet } \\ \text { IMM go-R/R }\end{array} \text { ART.M } & \begin{array}{l}\text { pa:pa=kinos } \\ \text { father_of=ART.F.A }\end{array} & \text { majni } \\ \text { my_as child } & \\ \text { OBL-ART.N radiyo } & \text { radio } \\ \text { 'The father of my daughter went to the radio (station) earlier today.' [tx] }\end{array}$

$\begin{array}{lllll}\text { no-kos } & \text { kwey } & \text { tu:vuy jayna } & \text { kiro' } & \text { joy-cheł } \\ \text { OBL-ART.N.A IMM dawn DSC } & \text { DEM.PL.A } & \text { go-R/R } \\ \text { 'They had left today at dawn already.' } & \quad[\mathrm{tx}] & \end{array}$

The occurrence of the particle nokowa outside and inside a noun phrase is illustrated by (14) and (15), respectively:

$n$-as $\quad$ tojet-wa=as piyesta nokowa
OBL-ART.N $\quad$ pass-NMZ=ART.N fiesta right_now
jiwa-te-na=y'ti $\quad$ rey
come-APPL-DR=1PL MOD
'When the fiesta is over we will bring (her) again.' [tx

$\begin{array}{llllll}\text { di:ra } & \text { tat } & \text { koro' } & \text { kos } & \text { nokowa } & \text { piyesta } \\ \text { still } & \text { EV } & \text { DEM.N.A } & \text { ART.N.A } & \text { right_now } & \text { fiesta } \\ \text { 'There will still be a fiesta, they say.' } \quad[\mathrm{tx}] & & \end{array}$

The TAM particle loy is the only one that never occurs inside a noun phrase, but normally right before the predicate, as in (16). ${ }^{8}$

$\begin{array}{llllll}\text { jayna loy } & \text { rey } & \text { it } & \text { joy-chet ma' } & \\ \text { DSC ITN } & \text { MOD 1INTR go-R/R } & \text { my_mother } \\ \text { 'I'm already leaving again, mother.' } \quad[\mathrm{tx}] & \end{array}$

None of these particles is grammatically obligatory. For example, the particle $l a$, which indicates the previous occurrence of a situation, is not needed to indicate past tense in general. The phrase nos walaylo 'in the afternoon' in (17) also refers to an afternoon in the past (as indicated by the article $o s$, see 3 below), but it is not specified as the previous afternoon, as was the case in (11) above.

8 Inside an NP, the particle loy is a marker of negation. 


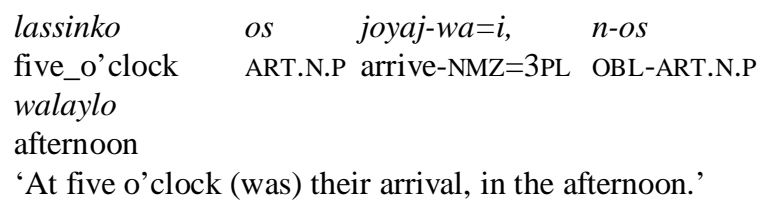

$[\mathrm{tx}]$

Likewise, the particle kwey is not obligatory in contexts that refer to a time on the day of speaking, as is the case of (18) (see 3.2. below for the 'immediate past' interpretation of the absential article $k o s)$ :

$$
\begin{aligned}
& \text { jayna kino' chi: chi no-kos ima:yoj } \\
& \text { DSC DEM.F.A MD go_out OBL-ART.N.A morning }
\end{aligned}
$$

The particles loy and nokowa are not obligatory markers of future tense either. The pair in (19) shows that loy is not obligatory:

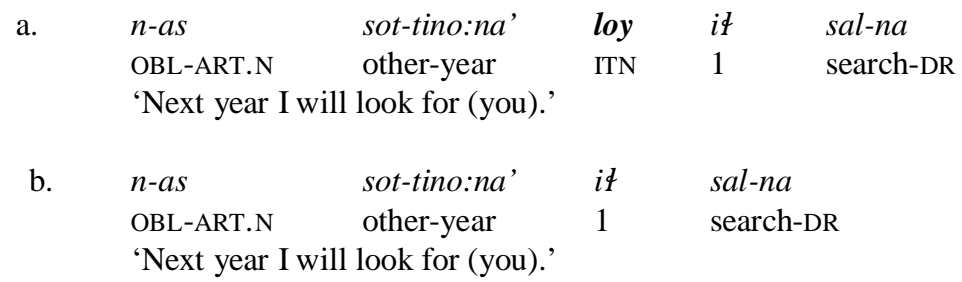

Example (20) is comparable in structure with (14) above. Here, however, future reference is made without the particle nokowa. ${ }^{9}$

$\begin{array}{lllll}n \text {-as } & \text { vakasyon ... } & \text { it } & \text { joy-chet } n \text {-as } & \\ \text { OBL-ART.N } & \text { holiday } & \text { 1INTR } & \text { go-R/R } & \text { OBL-ART.N } \\ \text { vayet-wa } & \text { n-iy'bikwet } & & & \\ \text { see-NMZ } & \text { OBL-PRO.2PL } & & \\ \text { 'In the holidays }[\ldots] \text { I'll go to see you.' } & {[\mathrm{tx}]}\end{array}$

In texts, the TAM particles only occur to establish the time of the topic of discourse, typically at the beginning of a text or passage (see, for instance, (10) above). Once the discourse time has been established, the particle does usually not occur again. For example, in the discourse preceding the sentence in (17) above, the discourse time had been established as the previous day.

9 Depending on the context, this clause can also have a habitual meaning: '... I always come to see you' (see 3.2.). 


\section{Spatio-temporal reference}

Despite the fact that there is no verbal tense morphology in Movima and that the TAM particles are not grammatically obligatory, sentences like those in (17)-(20) above do contain temporal information. In (17), it is asserted that the described situation has occurred in the past, i.e. before the day of speaking. Example (18) is unambiguously interpreted as describing a situation that has occurred on the same day, but previous to the moment of speaking. Example (19) and (20) clearly refer to a nonpast time. These meanings are brought about by the form of the article of one or more noun phrases in the clause. This mechanism is described in this and the following sections.

Movima has a rich inventory of referential elements: personal pronouns, articles, and demonstratives. They all have highly specific deictic properties, always indicating number, gender, and presence or absence of the referent. For absent referents, articles (but not pronouns, and demonstratives only in restricted contexts) additionally indicate whether the referent is still in existence or whether it has ceased to exist. This property makes the article the main carrier of temporal information in Movima. Its forms are given in Table 1.

Table 1. The Movima article

\begin{tabular}{lllll}
\hline & masculine & feminine & neuter & plural \\
\hline presential & us & i'nes & as & is \\
absential & kus & kinos & kos & kis \\
"past" & us (usos) & isnos & os & is (isos) \\
\hline
\end{tabular}

The article is defined by the fact that it is obligatorily followed by a content word, together with which it forms an NP. It does not mark definiteness, which is usually inferred from the context. For explicit definite reference to an entity present at the speech situation, a demonstrative can be used (which also indicates visibility, position, and relative distance; see Haude 2006: 174ff.). For explicit definite reference to an entity absent from the speech situation, the deictic adverb ney 'here' is placed right after the article:

$$
\begin{aligned}
& \text { ma'nes kis ney nonlo:-ba } \\
& \text { tasty ART.PL.A here milk-BR.round } \\
& \text { 'Those milk cakes are tasty.' [tx] }
\end{aligned}
$$

The following sections elaborate on the temporal-deictic function of the article.

3.1. Concrete referents: presence, absence, ceased existence

To start with, consider the examples in (22):
a.
as
pa:ko

[Linguistisc he Arbeiten: Musterseiten Sammelba nd] 


$\begin{array}{ll} & \begin{array}{l}\text { ART.N } \\ \text { 'the dog' }\end{array} \\ \text { b. } & \begin{array}{l}\text { kos } \\ \text { ART.N.A } \quad \text { pag } \\ \text { 'the/a dog (absent)' }\end{array} \\ \text { c. } & \begin{array}{l}\text { os } \\ \text { ART.N.P } \\ \text { 'the/a dog (past)' }\end{array}\end{array}$

The NP in (22)a, with the presential neuter article as, is used for reference to a dog that is present near the speech situation, for example in sight or somewhere in the same house or compound. It can also have a generic meaning, referring to the species of dogs. ${ }^{10}$ The NP in (22)b, with the absential article kos, refers to a dog that exists somewhere else, but is not near the speech situation. The NP in (22)c, which contains the "past" article, is used to refer to a dog that by the time of speaking has ceased to exist (see 4.2 below for further elaboration). The article thus distinguishes two temporal categories: existence (present or absent) and ceased existence.

It can be seen in Table 1 that only the neuter and the feminine articles distinguish formally between presence, absence, and ceased existence. By contrast, in the masculine and the plural paradigm, the same form is used for present and for non-existing referents ( $u s$ for masculine and is for plural; the forms in brackets, usos and isos, are very rare and, according to speaker judgements, imply that the referents have ceased to exist a long time ago). These forms are best seen as homophonous morphemes with different meanings: when the referent is absent, the forms $u s$ or $i$ s automatically imply ceased existence, since otherwise, the absential absential forms kus or kis would be used. (The unmarked article is in (3) above, for instance, is used because the dogs referred to did not exist anymore at the time of speaking.)

In order to apply the past article, the referent must be conceived of as having ceased to exist completely. It cannot be used to refer to dead bodies or to objects that have simply lost their function (a common function of nominal tense marking in other languages; see Nordlinger and Sadler 2004): the referent must be physically "gone". Otherwise, the presential or absential article is used. Example (23) illustrates this for a glass that is broken, but whose remainders are still around; (24) shows it for a person that has died, but whose body is still in existence (at the time of the actual utterance, it is being taken to the cemetery; note that the adjunct phrase refers to the event of dying, not to the dead person; see 3.2).

$$
\begin{array}{lcc}
\text { bay }\langle a>\text { cho }=\text { us } & \text { as } & \text { wa:so } \\
\text { break }<\mathrm{DR}>=3 \mathrm{M} . \mathrm{A} & \text { ART.N } & \text { glass } \\
\text { 'He (absent) has broken the (present) glass.' }
\end{array}
$$

${ }^{10}$ It is because of this broader applicability of the presential article (see also 3.2.) that it is unmarked in the glossing. 

kinos senyo:ra
jala:yij $n$-os
kayni-wa=sne
ART.F.A señora
angry OBL-ART.N.P die-NMZ=3F.A
'The (absent) woman was angry when she died.' (lit.: “in her past dying”) [tx]

Likewise, the past article does not indicate that a possessive relation has ended, while the possessum still exists. Hence, it is not equivalent to nominal temporality markers such as the English prefix $e x$-, which indicates a loss of function or termination of a possessive relation, but not that the referent itself has ceased to exist.

A further condition for the applicability of the past article is that the referent must have ceased to exist before the day of speaking. When it has ceased to exist on the same day, then inevitably the absential article is used (25)a, and the past article would be ungrammatical (25)b; its adequate employment is illustrated in (25)c.
a.
$\begin{array}{lll}\text { kwey } & \text { it } & \text { kay kay } \\ \text { IMM } & \text { 1INTR } & \text { MD eat }\end{array}$
no-kos
OBL-ART.N.P bird
jokme
'Today I ate the/a chicken.'
b. kwey it kay kay $*_{n-o s}$ jokme
IMM 1INTR MD eat OBL-ART.N.P bird
c. la' je:mes it kay kay n-os jokme
ANT day 1INTR MD eat OBL-ART.N.P bird
'Yesterday I ate the/a chicken.'

While the Movima past article asserts that the referent has ceased to exist before the day of speaking, there is no such marker for future existence, as in some other languages with nominal tense marking like Guaraní. For entities that come into existence in the future, either the presential or the absential article is used (the conditions of choice are not yet clear):

\begin{tabular}{|c|c|c|c|c|}
\hline loy & it & ji:sa:-na & kis & lokro \\
\hline ITN & 1 & make-DR & ART.PL.A & stew \\
\hline \multicolumn{5}{|c|}{ 'I'll make stew.' } \\
\hline loy & it & jisa:-na & is & narasa:-mi \\
\hline ITN & 1 & make-DR & ART.PL & orange-BR.water \\
\hline
\end{tabular}

\subsection{Times and situations: a three-way temporal distinction}

The temporal-deictic function of the article is still more differentiated in NPs that refer to times (i.e., points in time or time spans) and situations (events, processes, states etc.). These NPs always contain the neuter article. Times are denoted by nouns such as je:mes 'day', 
walaylo 'afternoon' or tino:nak 'year'. NPs referring to situations contain derived nouns. The nominalizing suffix - $w a$ derives event-denoting nouns, and reduplication or suffixation of -niwa basically derive state-denoting nouns. Situation-denoting NPs are extremely common in Movima because they are used to form complement and adverbial clauses.

With time- and situation-denoting NPs, all three forms of the article (presential, absential, past) receive a temporal interpretation. The presential article is used in present (28), future (29), and habitual (30) contexts:

$$
\begin{array}{lllll}
\text { jayna } & \text { tojet } & \text { po:la } & \text { as } & \text { salmo-wa }=n k w e t \\
\text { DSC } & \text { very } & \text { late } & \text { ART.N } & \text { return-NMZ }=2 \mathrm{PL}
\end{array}
$$

'You (pl) are coming back very late.'

(lit.: "Your returning is very late.") (Context: addressees are just coming back) [tx]

$\begin{array}{lllll}n \text {-as } & \text { sot-tino:nak } & \text { loy } & \text { if } & \text { sal-na } \\ \text { OBL-ART.N } & \text { other-year } & \text { ITN } & 1 & \text { search-DR }\end{array}$

'Next year I will look for (you).' $\quad[\mathrm{tx}]$

$\begin{array}{llll}\text { jampa } & \text { inta chot } & \text { n-as } & \text { kay-wa } \\ \text { do_like } & \text { PRO.1SG HAB } & \text { OBL-ART.N } & \text { eat-NMZ } \\ \text { 'I always do like this when I eat.' (lit.: “... at my eating.”) } & \text { [tx] }\end{array}$

The absential article indicates that the time or situation has occurred earlier on the same day, as is the case of (31) (partly repeated from (18) above; see also (13) above) and (32). (The absential demonstrative kino' in (31) and the masculine article kus in (32) are used because the persons referred to are absent; they do not have a temporal implication.)

$$
\begin{array}{llcl}
\text { jayna kino' } & \text { chi: chi } & \text { no-kos } & \text { ima:yoj } \\
\text { DSC DEM.F.A } & \text { MD go_out } & \text { OBL-ART.N.A } & \text { morning } \\
\text { 'She (absent) has gone out (today) in the morning.' [tx] } &
\end{array}
$$

$$
\begin{array}{llll}
\text { kwey } \quad \text { it } & j i<w a \sim>w a & \text { no-kos } & \text { sa sal-wa } \\
\text { IMM } \quad \text { IINTR } & \text { come<MD > OBL-ART.N.A } & \text { DR } \sim \text { search_for-NMZ } \\
\text { kus } & \text { Ernan Cholima } & \\
\text { ART.M.A } & \text { E. } \quad \text { Ch. } \\
\text { 'I came earlier today to look for Ernan Cholima.' }
\end{array}
$$

The past article indicates that the time or situation has occurred before the day of speaking, as in (33) (partly repeated from (17) above) and (34). (The ending $t$ instead of $s$ on the article in (34) marks the first person possessor; see Haude 2006: 141, 228.)

$$
\begin{array}{lll}
\text { lassinko } & \text { os } & \text { joyaj-wa } w i \\
\text { five_o'clock } & \text { ART.N.P } & \text { arrive-NMZ=3PL } \\
\text { 'At five o'clock (was) their arrival.' [tx] }
\end{array}
$$

$\begin{array}{llll}n-\boldsymbol{o t} & \text { dichi<ye: > ye tot } & \text { manes-pa:-na } \\ \text { OBL-ART.N.P.1 } & \text { child<NMZ > } & \text { very } & \text { tasty-APPL-DR }\end{array}$




\author{
as tadoy-ni \\ ART.N sweet-PRC \\ 'When I was a child, oh dear how much I liked sweets.' [tx]
}

The three-way temporal distinction with phrases referring to times and situations can be explained by the fact that these are abstract concepts that, unlike concrete entities, do not have a spatial location (see also Haude 2006: 169f.). Therefore, the absential article can unambiguously be used for temporal instead of spatial deixis.

At the same time, there is a direct parallel with NPs denoting concrete entities, whose referent must have ceased to exist in order to be referred to with the past article. In the case of times and situations, the absential and past forms can be used only when the situation is concluded. A situation that has started in the past but is going on in the present is always referred to with the presential article:

$\begin{array}{llllll}\text { jayna } & \text { rey } & \text { kaw-tinonak } & \text { as } & \text { rey } & \text { ney-niwa }=y ' t i \\ \text { DSC } & \text { MOD } & \text { much-year } & \text { ART.N } & \text { MOD } & \text { here-NMZ=1PL } \\ \text { 'It is many years already that we are here.' } & {[\mathrm{tx}]}\end{array}$

Its function in time- and situation-denoting NPs shows that the article distinguishes three major tense categories (like the particles discussed in 2.3.): past (before the day of speaking), immediate past, and nonpast. A closer observation of the examples in 2.3. above (in particular, (10), (11), (13), and (14)) reveals that the form of the article in this type of NP coincides with the TAM particle that establishes the time of the context.

\title{
3.3. Absolute concepts: no spatio-temporal differentiation
}

Certain NPs do not participate in the three-way distinction of deictic reference, but generally contain the presential article. These NPs refer to concepts that are highly timestable, do not change location, and are assumed to be generally known. I refer to these concepts as "absolute concepts", since their identifiability does not depend on their spatial and temporal location relative to the speech situation. ${ }^{11}$ Geographical locations (36), institutional buildings (37), and personalities of religious worship (38) are concepts of this type (again, the $t$ on the article in (38) marks the first-person possessor):

$\begin{array}{lll}\text { bo rey isne } & \text { kino' n-as } & \text { Tirinra } \\ \text { because MOD PRO.3F.A } & \text { DEM.F.A OBL-ART.N } & \text { Trinidad } \\ \text { 'Because she (absent) is in Trinidad.' } & \text { [tx] } \\ \begin{array}{lll}\text { tek-ka-ye:-chet } & \text { ena' } & \text { nosdé } \\ \text { kick-MLT-BE.Person-R/R } & \text { DUR.STD } & \text { over_there }\end{array}\end{array}$

${ }^{11}$ They constitute a subclass of Löbner's (1985) “functional concepts”, which "exist independently of the particular situation referred to" (Löbner 1985: 279). However, in addition to being considered as independently identifiable, absolute concepts are fixed in space and time, and this is what determines the choice of the unmarked article.

[Linguistisc he Arbeiten: Musterseiten Sammelba nd] 


$$
\begin{array}{ll}
n \text {-as } & \text { ele:siya } \\
\text { OBL-ART.N } & \text { church }
\end{array}
$$

'They are kicking each other over there at the church.' (speaker is at home, far from the church) [tx]

$\begin{array}{llll}\text { uf } & \text { pa:pa=n } & n \text {-as } & \text { ari:wa che } \\ \text { ART.M.1 } & \text { father_of=2 } & \text { OBL-ART.N } & \text { top and } \\ \text { i'neł } & \text { ma:ma=n } & d i \text {, } & \text { ma:ma=u } \\ \text { ART.F.1 } & \text { mother_of=2 } & \text { REL } & \text { mother_of=3M }\end{array}$

'our (incl.) father up there and our (incl.) mother, who is his mother (i.e. Jesus and Mary)' [tx]

A similar case is generic reference, which is also carried out with the presential form (see 3.1. above). Consider (39) (as well as the phrase as tadoyni 'sweets' in (34) above):

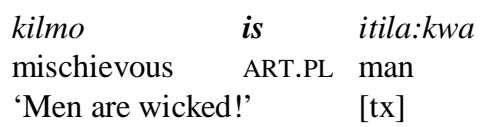

NPs referring to habitually occurring times and situations, which also contain the presential article (see (30) above), can be considered as belonging to this class as well.

\section{Independent and propositional nominal tense marking in Movima}

\subsection{Independent nominal tense marking with an implicature effect}

In their cross-linguistic study on nominal tense marking, Nordlinger and Sadler (1994) argue that there are two types of nominal tense marking: either the nominal tense marker indicates temporal properties of the entity denoted by the nominal, or it determines the temporal interpretation of the entire proposition, similar to tense marking on verbs. In the first case, the marking of temporality on the nominal is independent from clausal tense, which is why Nordlinger and Sadler label it "independent nominal tense marking". In the second case, called "propositional nominal tense marking", the marking of temporality on the nominal contributes temporal information relevant to the clause as a whole.

The spatio-temporal marking on noun phrases in Movima is clearly a case of "nominal tense marking". In line with Nordlinger and Sadler's criteria, the article marks a temporal relation between the existence of the referent and the moment of speaking. The combination with different forms of the article is not restricted to particular types of content words (except perhaps those words that denote "absolute concepts", see section 3.3.). The temporal marking clearly involves dependent phrases, not predicate nominals. And when a noun phrase contains not a noun, but a verb (see (6)a above), it still has a concrete referent, whose spatio-temporal properties are indicated by the article. I will now turn to the question of whether we are dealing with the "independent" or the "propositional" type of nominal 
tense marking here.

The previous sections have shown that the spatio-temporal deictic properties of the article indicate properties of the referent in relation to the time and place of the utterance. The deictic categories can vary, depending on the type of referent (concrete entity vs. time/situation). They are summed up in Table 2.

Table 2. The spatio-temporal categories encoded by the article

\begin{tabular}{lll}
\hline & entity & time/situation \\
\hline presential & $\begin{array}{l}\text { present } \\
\text { "absolute" }\end{array}$ & $\begin{array}{l}\text { present } \\
\text { future } \\
\text { "absolute" (habitual) }\end{array}$ \\
absential & absent, in existence & $\begin{array}{l}\text { concluded earlier on } \\
\text { the same day }\end{array}$ \\
"past" & $\begin{array}{l}\text { absent, out of existence (before the } \\
\text { day of speaking) }\end{array}$ & $\begin{array}{l}\text { concluded before the } \\
\text { day of speaking }\end{array}$ \\
\end{tabular}

It can be concluded that Movima nominal tense marking is of the "independent" type: it locates the time at which the property denoted by the noun holds of the referent. That this is independent of the contextual tense is shown by the following examples, to be discussed below:
ajlomaj-ti
os
naye $-w a=n$
tell_about-IMP.DR
ART.N.P
marry-NMZ=2
'Tell (her) about your (past) marriage!' [tx]

$$
\text { loy it to'baycho-poj-chet }
$$

ITN 1INTR remember-CAUS-R/R

'I'll remember my late grandmother.'

$$
\begin{array}{ll}
n \text {-isnos } & \text { nonok } \\
\text { OBL-ART.F.P } & \text { my_grandparent }
\end{array}
$$

$$
\begin{aligned}
& \text { a'ko rey tała<kwa > } k w a=\text { os dokwe } \\
& \text { PRO.3N MOD seam<INAL >=ART.N.P my_dress }
\end{aligned}
$$

'This (a stitched strip of cloth) is the seam of my (former) dress (which does not exist anymore).'

The clauses in (40)-(42) all contain an NP with a past article, but they also contain a marker that rules out a clausal past-tense interpretation. In (40), this is the transitive imperative suffix (-ti); (41) contains a TAM particle implying future reference (loy, see 2.3. above), and the referential elements in (42) indicate a difference in temporal properties of possessor and possessee (the presential pronoun $a^{\prime} k o$ for the possessum, the past article for the possessor). In all three examples, the past article indicates ceased existence of the referent, but this is independent of the interpretation of the clause as a whole. These 
examples, therefore, clearly identify the past article as a marker of independent nominal tense.

However, except in cases like these, which contain elements that explicitly indicate nonpast tense, the past article always determines the interpretation of the entire clause. This could already be observed in (1) and (2) above, repeated in (43) (with the absential construction in (43)b added).
a.
kay-a:-poj
eat-DR-CAUS
as
pa:ko
ART.N
$\operatorname{dog}$
'I fed/am feeding/will feed the dog (present).'
b. kay-a:-poj kos pa:ko
eat-DR-CAUS ART.N.A dog
'I fed/will feed the/a dog (absent).'
$\begin{array}{llll}\text { c. } & \text { kay-a:-poj } & \text { os } & \text { pa:ko } \\ & \text { eat-DR-CAUS } & \text { ART.N.P } & \text { dog }\end{array}$
'I fed the/a dog (that is now dead and gone).'

The past interpretation of a clause like (43)c can be understood easily, since it is most common to talk in a past context about entities that have ceased to exist. If the article only indicated loss of function or possession, such as ex- or former in English, we would expect to find it used more frequently in nonpast contexts, as well. Thus, we are dealing here with independent nominal tense marking that has an effect on the temporal interpretation of the proposition. So far, this is an effect of implicature only and should not be considered tense marking (see Comrie 1985).

However, even though implicational, the article provides temporal information consistently throughout the discourse. This is mainly due to the fact that in Movima, subordination is carried out through nominalization, which derives nouns whose referents are highly sensitive for temporal location (see 3.2.). This effect can be observed in (44)a-c (note that the existence and presence of the fence, as chakdi, remains constant):
a. jayna it
it ba:lomaj
DSC 1INTR finish
$n$-as
OBL-ART.N
ji:sa-na:-wa
as chakdi
ART.N fence
'I'll finish making the (present) fence.' (lit.: "with my making the fence”) (I'm still building it)
DSC 1INTR finish
as chakdi
ART.N fence
b. jayna it ba:lomaj
'I just finished making the (present) fence.' (today)
c. jayna it ba:lomaj n-os ji:sa-na:-wa 


\author{
DSC 1INTR finish OBL-ART.N.P make-DR-NMZ \\ as chakdi \\ ART.N fence \\ 'I finished making the (present) fence.' (before today)
}

Still, while the propositional tense-marking effect of the article is to a large extent due to implicature, there are signs that the article also has the potential of indicating propositional tense directly, as the following section will demonstrate.

\title{
4.2. The article as a marker of propositional tense
}

In the previous sections I have shown how the article indicates the location and existence of its referent. However, this was a slight simplification of the facts. First of all, it has to be kept in mind that a speaker cannot always know for sure whether an absent discourse referent is still in existence or not. The choice of the article only reflects the speaker's assumptions to that effect.

Second, also in Movima it does often not really matter whether an entity still exists or not. In fact, entities that are not relevant to the speaker at the time of speaking are generally referred to with the past article in past-tense contexts, independently whether they still exist or not. Typically, inanimate objects, like the car in (45), are referred to with the past article in past-tense contexts, even though they may still be existing somewhere (the situation narrated in (45) had only taken place on the previous day):

$\begin{array}{llll}\text { jayna lista } \quad d a & \\ \text { DSC } & \text { ready } \quad \text { DUR.NSTD } & \text { OBL-ART.N.P } \\ \text { joyaj-wa }=\text { os } & \text { awto } & \text { jayna } \\ \text { arrive-NMZ=ART.N.P car } & \text { DSC } \\ \text { 'She was ready when the car arrived.' } \quad \text { [tx] }\end{array}$

Example (46) illustrates the use of the past article with reference to a spider that has explicitly not been killed and may thus still be alive. However, here, as in (45) above, the past article is used because what is relevant to the speaker is to maintain temporal reference in discourse, and not the possible ongoing existence of the spider:

\begin{tabular}{llll} 
kas & rey & \multicolumn{2}{c}{ tikoy-na:-wa--as, } \\
NEG MOD & kill-DR-NMZ--3N.A \\
os & si:wa & merek \\
ART.N.P & spider & big \\
'I didn't kill it, the big spider.' & [tx]
\end{tabular}

In past contexts, even NPs referring to living human beings can contain the past article. This is also the case when the person referred to is not relevant for the speaker at the time of speaking. This is the case in (47):

$$
\text { jayna baw<a>ra='ne os itila:kwa nokodé }
$$


DSC pay $\langle$ DR $>=3 F \quad$ ART.N.P man over_there

'She has already paid the/a man over there.' ${ }^{12}[\mathrm{tx}]$

In contrast, living humans that still play a role in the life of the speaker are normally referred to by the presential (48) or absential (49) article (depending on their location), even if the narrated situations have occurred a long time ago:

$\begin{array}{lll}n \text {-os } & \text { to }<\text { chi } \sim \text { chik- } a=\text { 'nes } & \text { majni } \\ \text { OBL-ART.N.P } & \text { little<NMZ >-LV=ART.F } & \text { my_child } \\ \text { as-na=y'ti } & n \text { - } a s & \text { Peru } \\ \text { sit-DR=1PL } & \text { OBL-ART.N } & \text { Peru }\end{array}$

'When my (present) daughter was little (lit.: "at the (past) being small of my (present) daughter"), we lived in El Perú.' [tx]

$\begin{array}{lllll}\text { kinos } \quad \text { ay'ku } & \text { beyka } & n \text {-os } & \text { choy } & \text { rey } \\ \text { ART.F.A my_aunt } & \text { poor } & \text { OBL-ART.N.P } & \text { really } & \text { MOD } \\ \text { tolkos }<y a \sim>y a=s n e & \ldots & & \\ \text { girl<NMZ >=3F.A } & & & \\ \text { 'My poor (absent) aunt, when she was a girl... } & {[\mathrm{tx}]} & \end{array}$

However, sometimes the past article is used (by some speakers apparently more often than by others) even when the nominal referent is present at the speech situation or when its existence is relevant for the speaker. For instance, in (50) the speaker refers to her own body with the past article, something which is not normally done. In (51), the speaker's parents are referred to with the past article (which, in the case of the masculine, is the unmarked form $u s$ ), even though shortly before it had been pointed out that they are still alive. The article is chosen here not according to a deictic property of the referent, but according to the time of the context.

$\begin{array}{lllll}\text { jayna } & n \text {-os } & \text { imayni } & \text { jayna } & \text { tivijni } \\ \text { DSC } & \text { OBL-ART.N.P } & \text { night } & \text { DSC } & \text { hurt } \\ \text { os } & \text { chodo:wi } & & & \end{array}$

ART.N.P my_stomach

'Then at night, my stomach hurt.' [tx]

$\begin{array}{lll}\text { n-asko } & \text { ela-na=us } & p a \\ \text { OBL-PRO.3N.A } & \text { leave_behind-DR=ART.M } & \text { my_father } \\ \text { isnos } & m a\end{array}$

12 With human referents, the neuter article has a nonspecific or derogatory reading. 
These examples show that the choice of the article is not only determined by properties of the referent, thereby having an implicational effect on the temporal interpretation of the proposition. It can also serve as a device for directly marking temporal relations in discourse. Here, the Movima article is clearly a marker of propositional nominal tense.

\subsection{From independent to propositional nominal tense}

I have shown that in principle, nominal tense marking in Movima is of the independent type, the choice of the article depending on deictic properties of the referent and having only an implicational effect on the temporal interpretation of the clause. However, depending on the relevance of the referent and on the priority the speaker may give to the marking of discourse tense, the past article can also be used to mark discourse tense directly, thereby functioning as a marker of propositional nominal tense. It is therefore possible to speak of a gradual shift of nominal tense marking in Movima from purely independent towards propositional. This can be represented as in Figure 1:

\section{independent $\longrightarrow$ propositional}

$\begin{array}{llll}\text { property } & \text { ceased existence } & \text { absent referent } & \text { past article marks past } \\ \text { of referent } & \text { of referent implies } & \text { whose existence is } & \text { tense in discourse }\end{array}$
past tense in discourse irrelevant: marking according to context

Figure 1. The shift from independent to propositional nominal tense marking

In Figure 1, prototypical independent nominal tense marking is given on the left-hand side. Here, a temporal property of the referent is marked, independently of the discourse tense (see (40)-(42) above). The fact that this marking usually has an effect on the interpretation of the proposition as a whole (as shown in (43) and (44)) is a step towards propositional temporal marking. When entities are referred to by the past form, even though they are still in existence (as in (45)-(47)) and even present or relevant to the speaker (as in (50)-(51)), the article does not indicate a temporal property of the referent anymore. It serves as a propositional nominal tense marker that provides temporal information of the clause as a whole. This shift can be seen as an instance of what Traugott has termed the "subjectification" effect in grammaticalization (Traugott 1995, 1999): the article is used to express the speaker's attitude towards the propositional content, and through conventionalization of this use, the article grammaticalizes into a marker of propositional tense.

\section{Discussion}

[Linguistisc he Arbeiten: Musterseiten Sammelba nd] 
It was shown that Movima displays the phenomenon Nordlinger and Sadler (2004) label "nominal tense marking". However, it is worth discussing in how far this phenomenon can be seen as tense marking at all, comparable to verbal tense marking in other languages, or if we are not rather dealing with something different.

First of all, it may be asked whether the Movima article does not have the function of indicating aspect or mood rather than tense. The fact that an entity must have ceased to exist completely or that a situation needs to be concluded so that the past article can be applied, points to a possible analysis as an aspect rather than a tense marker. However, as was shown, the article serves to locate situations in time in relation to another time (the moment of speaking). Of the categories tense, mood, and aspect, only tense has this property (see Chung and Timberlake 1985). That there are aspectual categories involved is no contradiction: the correlation between past tense and completive aspect is due to the fact that a situation ongoing at the speech moment has not been completed. Modal categories may be part of the meaning of the article in that the perspective of the speaker is crucial, sometimes regardless of the actual or ceased existence of the referent. ${ }^{13}$ However, the article does not seem to qualify the proposition as a whole in these cases.

A further question is whether the category of tense can be applied to nominal expressions at all. Tonhauser (2006) argues that from a semantic viewpoint, verbal tense and the temporal interpretation of NPs are fundamentally different. It would, therefore, be more appropriate to speak about nominal temporality rather than about tense. This issue is worth considering in some detail.

In addition to being a nominal category, the properties of the Movima article also lack some other features typically associated with tense marking. Tense is generally defined as an inflectional category that is grammatically obligatory under certain circumstances (see Dahl and Velupillai 2005: 266). In Movima this is not the case; while the article is an obligatory part of an NP, its form is in the first place determined by whether the speaker believes an absent referent still to be in existence or not and by the relevance s/he attaches to this fact, in comparison to the relevance s/he attaches to temporal reference in discourse. At the present stage of the possible grammaticalization process from independent to propositional tense, the context does not demand a particular form of the article, as is the case for canonical verbal tense marking. Another typical feature of tense is that it is an anaphoric category (see Tonhauser 2006: 28). As was shown, the Movima article only displays anaphoricity to a limited degree, namely when its form is chosen according to the contextual time (see 4.2.). In many other cases, however, it is chosen according to properties of the referent.

Thus, if interpreted in the narrow, theoretical sense, according to which tense does not apply semantically to nominals at all, the Movima system would have to be seen as something completely different from tense-marking systems. However, if the notion of tense is taken as a functional notion, i.e. as a deictic category of temporality, the Movima article system is a tense-marking system that marks the relation between two times. This perspective makes it possible to see one of the many different strategies that languages use

13 This is particularly relevant for the choice of the absential article in nonpast contexts, cf, (26) and (27) above. More research is needed here. 
to encode temporal relations, and thereby provides more insight into the human cognitive capacities.

\section{References}

Chung, Sandra, and Alan Timberlake (1985): Tense, aspect, and mood. - In: Shopen, Timothy (ed.): Language typology and syntactic description, Vol. 3: Grammatical categories and the lexicon, 202-258.Cambridge: Cambridge University Press.

Comrie, Bernard (1985): Tense. - Cambridge: Cambridge University Press.

Croft, William (2003): Typology and Universals. Second edition. - Cambridge: Cambrigde University Press.

Dahl, Östen and Viveka Velupillai (2005): Tense and Aspect. - In: Martin Haspelmath et al. (eds.), World Atlas of Language Structures, 266-272. Oxford: Oxford University Press.

Haude, Katharina (2004): Nominal tense marking in Movima: nominal or clausal scope? In: Leonie Cornips and Jenny Doetjes (eds.): Linguistics in the Netherlands 2004, pp. 8090. - Amsterdam/Philadelphia: Benjamins.

--- (2006): A grammar of Movima. PhD dissertation, Radboud University Nijmegen. (Available at http://webdoc.ubn.ru.nl/mono/h/haude_k/gramofmo.pdf)

--- (2009a): Reference and predication in Movima. - In: Epps, Patience and Alexandre Arkhipov (eds.): New Challenges in Typology: Transcending the Borders and Refining the Distinctions, pp. 323-342. Berlin: Mouton de Gruyter.

---- (2009b): Hierarchical alignment in Movima. - International Journal of American Linguistics 75(4): 513-532.

--- (2010a): The intransitive basis of Movima clause structure. - In: Gildea, Spike and Francesc Queixalós (eds.): Ergativity in Amazonia, 285-315. Amsterdam/Philadelphia: Benjamins.

---- (2010b): 'She kisses her late husband' = 'she kissed her husband': nominal tense marking in Movima. - In: Cyscouw, Michael and Jan Wohlgemuth (eds.): Rara and Rarissima, 95-116. Berlin/New York: Mouton de Gruyter.

Löbner, Sebastian (1985): Definites. - Journal of Semantics 4: 279-326.

Nordlinger, Rachel and Louisa Sadler (2004): Nominal tense marking in crosslinguistic perspective. - Language $80,776-806$.

Tonhauser, Judith (2006): The temporal semantics of noun phrases: evidence from Guaraní. PhD dissertation, Stanford University.

Traugott, Elizabeth (1995): Subjectification in grammaticalization. - In: Wright, S. \& Stein, D. (eds.): Subjectivity and subjectivization, 31-54. Cambridge: Cambridge University Press.

---- (1999): The rhetoric of counter-expectation in semantic change: a study in subjectification. - In Blank, A. and P. Koch (eds.) Historical semantics and cognition, 177-196. Berlin: Mouton de Gruyter. 